4 Chin SP, Abou Madi MN, Eurin B et al. Blood loss in total hip replacement: extradural vs phenoperidine analgesia. Br J Anaesth 1982; 54: 491-5.

5 Mannucci PM. Desmopressin: a nontransfusional form of treatment for congenital and acquired bleeding disorders. Blood 1988; 72: 1449-55.

6 Kobrinsky NL, Letts MR, Patel LR. 1-desamino-8-Darginine vasopressin (Desmopressin) decreases operative blood loss in patients having Harrington rod spinal fusion surgery. Ann lnt Med 1987; 107: 446-50.

7 Salzman EW, Weinstein MJ, Weintraub RM et al. Treatment with desmopressin acctatc to reduce blood loss after cardiac surgery. N Engl J Med 1986; 314: 1402-6.

8 Hackman T, Gascoyne RD, Naiman SC et al. A trial of desmopressin (1-desamino-8-D-arginine vasopressin) to reduce blood loss in uncomplicated cardiac surgery. N Engl J Med 1989; 321: 1437-43.

9 Bidstrup BP, Royston D. Sapsford RN et al. Reduction in blood loss and blood use after cardiopulmonary bypass with high dose aprotinin (Trasylol). J Thorac Cardiovasc Surg 1989; 97: 364-72.

10 Kang YG, Martin DJ, Marquez $J$ et al. Intraoperative changes in blood coagulation and thromboelastographic monitoring in liver transplantation. Anesth Analg 1985; 64: 888-96.

11 Spiess BD, Tuman KJ, MCCarthy RJ, Ivankovich $A D$. Thromboclastography as an indication of post-cardiopulmonary bypass coagulopathies. J Clin Monit 1987; 3: 25-30.

12 Consensus conference on perioperative red blood cell transfusion. JAMA 1988; 260: 2700-3.

13 Arieff $A$ I. Hyponatremia, convulsions, respiratory arrest, and permanent brain damage after elective surgery in healthy women. N Engl J Med 1986; 314: 1529-35.

14 London MJ. Ho JS. Triedman JK. A randomized clinical trial of $10 \%$ pentastarch (low molecular weight hydroxyethyl starch) versus $5 \%$ albumin for plasma volume expansion after cardiac operations. J Thorac Cardiovasc Surg 1989; 97: 785-97.

15 Zarins CK, Rice CK, Peters RM et al. Lymph and pulmonary response to isobaric reduction in plasma oncotic pressure in baboons. Circ Res 1978; 43: 925-30.

\section{Blood product utilization and management in Canada}

\author{
Gershon H. Growe MD \\ Department of Medicine (Pathology), Transfusion \\ Service, Vancouver General Hospital, University of \\ British Columbia
}

\begin{abstract}
The utilization of blood for transfusion in Canada has remained at 900,000-950,000 units p.a. for the past six years. Donation has decreased slightly from a peak of 1,200,000 units p.a. in 1989. The use of fresh plasma and cryo-precipitate has decreased while the use of platelets has doubled in the past six years. The increased use of albumen cannot be explained. In Vancouver, all anaesthesia residents take a compulsory transfusion medicine rotation which appears to be successful in rationalizing transfusion practice.
\end{abstract}

Aux fins de transfusions, on a utilisé de 900000 à 950000 unités de sang par an au Canada au cours des six dernières années. Les dons de sang ont un peu fléchi après un maximum de 1200000 unités atteint en 1989. L'usage de plasma frais et de cryoprécipité a diminué mais la demande en plaquettes sanguines a doublé en six ans. L'engouement récent pour l'albumine est surprenant. A Vancouver, tous les résidents en anesthésie font un stage en hématologie transfusionnelle ce qui semble contribuer à une attitude rationnelle envers les transfusions.

Since 1983 there has been an unique stress on the blood transfusion systems of the world including that of Canada because of the concern about HIV and other viral infections. Not only has this made patients and doctors less enthusiastic about transfusing blood and blood products, but it has also had an unusual effect in some communities of discouraging blood donors. There has been a vigorous attempt to educate people in this regard. In Canada between 1983 and 1989 there was a slight increase in total blood collections from approximately $1,100,000$ to $1,200,000$. With the introduction of HIV testing, donor self-exclusion at site, and now hepatitis $\mathrm{C}$ and HTLV-1 testing there has been a decrease of $5 \%$ of usable blood once drawn. Red cell utilization in Canada has remained stable between 900,000 and 950,000 units over the six years despite the introduction of many new transplant and aggressive trauma programs. Therefore, this pattern likely reflects a more judicious use of red 
cells. In our hospital we found that there was a considerable decrease in the number of recipients even though the gross amount of red cell transfusion remained the same.

There has been a progressive drive to collect more fresh plasma for fractionation purposes and after a usage peak in 1985-86 the current levels have decreased. From November 1990 the only whole plasma product available for transfusion in Canada will be frozen plasma (FP); this product is frozen within $24 \mathrm{hr}$ of phlebotomy. Cryoprecipitate production and usage has also decreased considerably since 1983 and this product is used mainly in the management of von Willebrand's disease. However, it is the richest source of fibrinogen and has been useful for treating consumptive states such as disseminated intravascular coagulation and also for treating fibrinolytic states which may occur during liver transplantation and heart surgery. There has also been interest in the use of cryoprecipitate for topical fibrin glue and this can be made in the laboratory prior to its application.

In contrast, platelet production and utilization have increased over the past decade. Platelets are obtained from random blond donors and also from single donors pheresed on cell separators. The use of platelets has doubled in the past six years. There is still a considerable problem with the out-dating of platelets because of their short five-day shelf life. Improvement in plasticizers, preservative solutions and atmospheric conditions are attempts to prolong platelet storage life. This high utilization of platelets reflects the aggressive ireatment of leukaemia and bone marrow transplant programs as well as the chemo-radiotherapy used in the treatment of solid tumours. The recognition of the platelet defect with massive transfusion has also led to a more rational and earlier use of platelets after one blood volume exchange when the platelet count has been shown to be depressed. There is still some doubt about the value of platelets in "microvascular bleeding" as this phenomenon is often multifactorial and may be more metabolic in origin than directly due to reduced platelet count or function.

Coagulation factor usage for haemophilia has remained stable. The newer highly purified concentrates, however, have increased the cost of these blood products considerably. Reconstructive and emergency surgery in haemophiliacs can be managed well with proper coagulation factor replacement. This should be done in centres where Factor VIII and Factor IX levels can be accurately assessed and followed. The usefulness of two non-plasma derived agents should also be noted. Antifibrinolytic agents have proved to be valuable in the management of dental surgery in haemophiliacs, as has DDAVP in the treatment of mild Haemophilia A and von Willebrand's disease.

There has been a notable and progressive increase in the use of albumin in this country, much of it without adequate explanation. Al the present time albumin, Factor
VIII, and IVIG, are the three most expensive fractions in use and exert a considerable driving force on the plasma industry both nationally and internationally. Five per cent albumin, although considerably more costly than dextrans or saline, is a good oncotic agent for use in resuscitation. However, it is not useful for long-term management of hypoalbuminaemic states and should never be used for intravenous hyperalimentation. The reason for the persistence of $25 \%$ albumin on the market remains a mystery as it has no specific value and usually is diluted to $5 \%$ before infusion.

At the Vancouver General Hospital our utilization of plasma products tends to parallel the national experience in Canada. We perform a considerable amount of reconstructive joint surgery in haemophiliacs and so utilize a good deal of Factor VIII and Factor IX concentrates. The Cell Separator Unit is present on site at our hospital and this can supplement our platelet needs which are large because of our haematology and organ transplant programs. We have utilized published reports such as the US Consensus Conference for the Use of Frozen Plasma to help promote the utilization of FP in our hospital and have also conducted audits on plasma and albumin utilization. One albumin audit showed that at least one-third of this product is used inappropriately and a recent FP audit suggested that a third of this product was also inappropriately administered. In order to improve the use of all blood products in the hospital through education and consultation we have hired a Blood Products Co-ordinator. This is a senior technical position in the Blood Transfusion Service and is supported in part by our hospital and by a grant from National Health and Welfare Research and Development. The activities of this individual over the past year-and-a-half suggest that all large hospitals with complex transfusion programs would benefit from someone working in this capacity.

A major innovation at our hospital was the introduction of a mandatory Transfusion Medicine Education rotation for the anaesthesia trainees. This program which began in 1984 has all senior residents spending two months with the Blood Transfusion Service to gain experience in the Blood Bank and to learn about transfusion practice and related coagulation investigation. During their rotation residents function as transfusion clinical consultants. The major emphasis is on correlation of blood product utilization tailored to coagulation and other haematology results. Indiscriminate transfusion practice is discouraged. Much attention as been shown to the intensive care areas, transplantation and emergency trauma programs. Residents are provided with a series of lectures and relevant literature and are encouraged to design and start a clinical research project. Their education is reflected by a qualitative improvement in blood product utilization in the surgical areas. 
Although we have not achieved optimal transfusion practice in this country, others are dealing with the issues raised in this symposium. The Canadian Blood Committee has taken a major interest in the cost and the utilization of blood products and has set about to try to understand and predict blood product utilization in the future. Not only have they looked at the problems of plasma fractionation, but they are also considering the implications of the introduction of new synthetic blood products such as recombinant Factor VIII, the potential implications of erythropoietin, and the usefulness of blood substitutes such as pyridoxalated $\mathrm{Hb}$ solution. These are among the many issues awaiting evaluation and introduction into our complex blood program.

\section{Suggested reading}

Perreault R. Personal Communication. Canadian Red

Cross BTS. Statistics 1983 to $1989 / 90$.

Canadian Red Cross Blood Transfusion Service - Clinical

Guide to Transfusion Products and Practices, 1987.

Growe $G H$, Sinclair $M$. New Directions for the Hospital Blood Transfusion Service. Can Med Assoc J 1988; 138 : 209-10.

Comprehensive Curricular Goals for Tcaching Transfusion Medicinc: The Curriculum Committec of the Transfusion Medicine Academic Awards Group. Transfusion, 1987; 29 : 438-46.

\section{Indications for perioperative blood transfusion in 1990}

\author{
Linda Stehling MD \\ Department of Anesthesiology, University of New \\ Mexico, Albuquerque, New Mexico, U.S.A.
}

\begin{abstract}
Rational transfusion practices are determined by clinical evaluation and utilization of appropriate laboratory tests. While the trend toward more conservative transfusion practices is laudable, blood transfusions should not be withheld because of fear of transfusion-transmitted disease. The blood supply is safer than ever before and advances in monitoring and laborato$r y$ testing are facilitating scientific approaches to blood administration.
\end{abstract}

L'évaluation clinique et l'utilisation appropriée de tests de laboratoire permettent une approche rationnelle des transfusions sanguines. La tendance vers une approche plus conser- vatrice face aux transfusions est lowable toutefois, on ne devrait pas indûment restreindre l'usage des transfusions par crainte des maladies qu'elles peuvent transmettre. Les stocks sanguins sont de plus en plus sécuritaires et l'amélioration du monitorage et des tests de laboratoire permettent une approche scientifique de la pratique transfusionnelle.

Approximately two-thirds of red blood cell transfusions are administered in the perioperative period, most by anaesthetists. In addition, a considerable proportion of the platelets and plasma are given to surgical patients.

Traditional transfusion practices are being reevaluated, primarily because of the fear of transfusion-transmitted disease. More conservative transfusion practices can also be attributed to concerns about the immunomodulatory effects of homologous transfusion. Although the mechanism is unclear, cancer patients who are transfused perioperatively have a worse prognosis than those with similar pathology who are not transfused. In addition, homologous transfusion may impair host defenses against bacterial infection and increase the risk of postoperative infection.'

Most recommendations for current transfusion practices are based on the statements of the Consensus Conferences on Perioperative Red Blood Cell Transfusion ${ }^{2}$ Platelet Therapy, ${ }^{3}$ and Fresh Frozen Plasma ${ }^{4}$ sponsored by the National Heart, Lung and Blood Institute. While these recommendations are the best available, further research is needed to provide a more scientific basis for transfusion practices.

The introduction of plastic bags and tubing in the 1950s led to the development of component therapy in the 1960s. The contemporary transfusion service can now provide $\mathbf{2 5}$ or more different blood products. Reliance on component therapy has led to more efficient utilization of the blood supply. Without fractionation, specific components will not be available when needed. Administration of unnecessary components is also avoided. Since the storage requirements for components differ, separation also permits each to be stored at optimal temperature to ensure maximal therapeutic benefit.

There has been a resurgence of interest in the use of fresh whole blood, especially related-donor transfusion in cardiac surgery patients. ${ }^{5}$ However, the identification of fatal graft-versus-host disease in several nonimmunocompromised patients has tempered this enthusiasm. ${ }^{6}$ While irradiation of donor blood may eliminate this problem by inactivating lymphocytes responsible for the disorder, it is unlikely that the use of fresh whole blood will become widespread because of the logistics of collection and testing as well as the lack of proven efficacy. ${ }^{7}$

\section{Indications for red blood cell transfusion}

It has been traditional for anaesthetists to insist that patients 